\title{
Problemas na Variante Tensa da Fala Carioca*
}

\author{
(Problems in the Tense Variant of Carioca Speech)
}

Angela FrançA

(CEDOCH-DL-USP)

\begin{abstract}
In this paper I reconstruct the rupture role carried out by Para o Estudo da Fonêmica Portuguesa (1953) in the Brazilian academic context of the 1950s in contrast with the "Normas para a boa pronúncia da lingua nacional no canto erudito" established in 1937 by the Congresso da Lingua Nacional Cantada. I claim that there is continuity between the phonetic point of view of the "Normas" and the phonemic point of view of the "Fonêmica" in what concerns the selection of the empirical problems to be analysed; but I also claim that there is discontinuity between the two lines of research when it comes to treating linguistics data.
\end{abstract}

KEY-WORDs: Mattoso Câmara; Phonemic; Phonetics; Congresso da Lingua Nacional Cantada.

REsumo: Este trabalho retoma o papel de ruptura desempenhado pela obra Para o Estudo da Fonêmica Portuguesa (1953), no contexto acadêmico brasileiro dos anos 50, fundamentado no contraste com as "Normas para a boa pronúncia da língua nacional no canto erudito", estabelecidas em 1937 pelo Congresso da Lingua Nacional Cantada. Parto da suposiz̧ão de que há continuidade entre o ponto de vista fonético e o ponto de vista fonêmico no que diz respeito a problemas empíricos tratados pelas duas linhas de pesquisa, mas defendo que há descontinuidade no que diz respeito ao modo de tratar os dados fônicos.

PaLAVRas-CHave: Mattoso Câmara; Fonêmica; Fonética; Congresso da Lingua Nacional Cantada.

\footnotetext{
* Os dados do presente texto foram extraídos da pesquisa efetuada para minha tese de doutorado, Para uma Historiografia de Resolução de Problemas: da 'Arte de Dizer' na Fala Carioca às Descrições da Variante Oral do Português Brasileiro (1937-1960). São Paulo/USP, 2003.
} 


\section{Introdução}

No recém-iniciado contexto acadêmico brasileiro de letras, línguas e literaturas, o falar carioca esteve no centro das atenções. No Congresso da Lingua Nacional Cantada - realizado na cidade de São Paulo, entre 7-14 de julho de 1937 -, o primeiro grupo de decisão no Brasil que enfrentou o problema de descrição da variante urbana do português brasileiro como língua padrão (cf. Affonso 1958) e instituiu as "Normas para a boa pronúncia da língua nacional no canto erudito" (1938) recomendou a pronúncia dita culta da fala carioca ${ }^{1}$ como o padrão ideal ou preferencial a ser seguido no país, certamente devido ao prestígio político e cultural da então capital federal. Por outras vias e motivações, a proposta inspiradora de Joaquim Mattoso Câmara Júnior (1904-1970), Para o Estudo da Fonêmica Portuguesa (1953: 57), privilegiou registro semelhante, que designou variedade coloquial tensa do Rio de Janeiro.

Minha contribuição em homenagem ao introdutor do estruturalismo no Brasil (e indiretamente até em Portugal), afirmação de Coseriu (1976[1968]: 20), com a qual concordam outros especialistas (Uchôa 1971, Naro 1972, Leite 1986, Altman 1998), será demonstrar o papel de ruptura que a Fonêmica exerceu nos parâmetros de análise então utilizados para a descrição do padrão fonológico, ou fonêmico, como o autor preferiu, da modalidade brasileira do português.

Retrospectivamente, as duas obras mencionadas, as Normas e a Fon $\hat{e}-$ mica, permitem identificar duas tradições brasileiras de pesquisa na história do estudo sobre a forma lingüística, de acordo com suas respectivas metodologias (Laudan 1977). Uma delas, a das Normas (doravante, NBP), estuda os sons atualizados na fala em si mesmos, no que têm de natural dos pontos de vista fisiológico (articulatório) e físico (acústico/auditivo), procedimentos usados na Fonética dita clássica; outra, a da Fonêmica, estuda a relação de entidades abstratas que organizam a estrutura daquela atualização e estabelece as unidades funcionais que servem para distinguir o sentido de morfemas e palavras, porque vê a língua como um sistema, um objeto autônomo.

\footnotetext{
1 Despida dos traços que mais tipicamente singularizam o falar carioca: "o 'chichiismo' [do] $s$ com som de $c h$ ou de $j$ (doch e lesjma - dois e lesma), o 'gargarismo' [do] $r$ forte, na denominação de Oiticica", a vocalização da líquida lateral final, por exemplo (cf. Affonso 1958: 139 e Anais 1938, respectivamente).
} 
Esta distinção já era assumida pela lingüística geral desde pelo menos a década de 30. Ao retomar os antecedentes do domínio de investigação que o Círculo Lingüístico de Praga traçara, Nikolaj Trubetzkoy (1890-1938), considerando a relação de oposição entre as duas disciplinas, apartou a Fonologia da Fonética: enquanto a Fonética era necessariamente atomista e 'naturalística', a Fonologia era universalista por natureza (cf. Trubetzkoy 1978[1933]). Foi na perspectiva universalista da fonologia de Trubetzkoy que o brasileiro Mattoso Câmara se engajou ao defender sua tese de doutoramento em 1949, publicada em 1953, em contraste, como se verá, às análises atomistas e naturalistas das NBP e de dois notórios foneticistas no período: Antenor Nascentes (1886-1966) e José Oiticica (1882-1957).

A título de ilustração, vejam-se exemplos das orientações fonética e fonêmica na descrição das vogais orais:

Quanto ao timbre as vogais se dividem em abertas, fechadas e reduzidas. Na palavra lado a vogal oral é aberta, na palavra rosa é reduzida. [É] aberta quando sôbre ela recai o acento tônico da palavra; e reduzida quando não recai. [...] $\mathrm{O} a$ do artigo definido, pronome oblíquo e preposição e o de as, são sempre reduzidos. $\mathrm{O} a$ das combinações à e às no sul do Brasil é quase reduzido; é muito pequena a diferença entre $a$ e $\grave{a}$, [e] as e às, [por isso] os freqüentes erros na escrita. [...] Na palavra café a vogal oral e é aberta, na palavra mêdo é fechada, na palavra bote é reduzida. [...] A vogal $e$ é reduzida, i.e., tem som aproximado de $i$, quando átona no fim das palavras [...]. Fora disto é reduzida também nas sílabas iniciais átonas em, en, es, ex: [...] pronuncie-se imbeber, incanto, istar, ixclamar, e em outros casos, ex.: perigo, menino, feliz etc. [...] A vogal $o$ é reduzida, tem som aproximado de $u$, quando átona, no fim das palavras [...] e em outros casos, ex.: política, colégio etc. Há indecisões a respeito do timbre do $e$ e do 0 . (Nascentes 1937/1938: 24, 44) ${ }^{2}$

O foneticismo naturalístico é que baralhou o problema ao procurar deduzir diferenças e estabelecer vários tipos de /a/, /i/, /u/. [...] São incluídos alofones e variantes combinatórios, facultativos gerais e até [...] estilísticos e facultativos individuais. $[\mathrm{O}] \mathrm{s}$ teoristas brasileiros mantêm-se no mesmo ponto de vista, e em especial põem de per si as variantes átonas, o que já é suficiente para criar um quadro complexo. [...] Ultrapassando as letras do alfabeto, temos, apenas, a mais, como fonemas distintos, as oposições entre /e/ e /è/ e /o/ e /ò/, que são nítidas e funcionais em português. Daí, as 7 vogais que facilmente se deduzem de séries vocabulares como /vidi/, /vedi/, /vèdi/, /vadi/ e /suqu/, /soqu/, /sòqu/, /saqu/. (Mattoso Câmara 1953b: 68-70)

2 Respeitou-se a grafia em todas as citações, mas nem sempre os parágrafos. 
Aquilo que era problema da perspectiva fonética não é problema para a perspectiva fonêmica (ou fonológica), pois Mattoso Câmara deu um tratamento funcional à organização da pronúncia coloquial (espontânea) carioca. Esse tratamento foi dado por meio da oposição de traços distintivos de natureza prosódica e de natureza articulatória, que estabelecem contrastes e associações entre as formas fônicas: não é a gradação 'sempre reduzida' > 'quase reduzida' que é relevante para a descrição do sistema vocálico, mas sim a distribuição do acento - como em sábia : sabia : sabiá.

$\mathrm{Na}$ confronto que estabeleço adiante, parto da suposição de que há continuidade entre o ponto de vista fonético e o ponto de vista fonêmico no que diz respeito aos problemas empíricos tratados pelas duas linhas de pesquisa. Entretanto, defendo que há descontinuidade no que diz respeito ao modo de tratar os dados fônicos e ao modo de encaminhar as soluções propostas para esses problemas. Exemplifico esses movimentos em duas questões concretas: o problema do timbre na distinção das vogais átonas e o da oscilação na pronúncia entre ditongo e hiato.

\section{O corpus de Mattoso Câmara em 1953}

Em trabalho anterior (França 2003), examinei um tópico intrigante que circunda os dados na Fonêmica (1953). Mattoso não explicitou como os coletou. Assumindo que ele conhecia de perto quais fatos ou fenômenos eram considerados anômalos (posto que irregulares) nas descrições fonéticas que antecederam sua Fonêmica, verifiquei que os corpora da análise de 1953 foram as NBP e os trabalhos de Nascentes (particularmente O Idioma Nacional, de 1937/1938 e as "Questões de Fonética", de 1939[1938]), além do rimário na poética brasileira, e, certamente, de dados extraídos do seu próprio idioleto.

Dos 80 dados fônicos que levantei, exaustivamente, na Fonêmica, $33,75 \%$ responderam por uma parte razoável do corpus construído pelo lingüista a partir da fala carioca já documentada. Quer dizer, um terço dos dados ali encontrados foram reaproveitados de estudos brasileiros feitos anteriormente. Há 18 exemplos retirados das NBP; 22 das obras de Nascentes; 4 do trabalho de Sousa da Silveira (1883-1967) e 2 de uma famosa 
carta de Oiticica (1955[1938]) a Nascentes. ${ }^{3}$ Tais índices sugerem que o exemplário de Mattoso de fato retomou, ao menos em parte, e de uma perspectiva fonêmica, questões fonéticas vistas como problemáticas por sua geração.

As questões retomadas foram as seguintes:

(1) multiplicidade de vogais classificadas quanto ao 'timbre', e a conseqüente imprecisão na caracterização das vogais ditas reduzidas ou surdas, por exemplo, $f(\varepsilon) l i z \sim f(e) l i z \sim f(i) l i z ;$

(2) pronúncia das vogais nasais, bła\}nana $\sim$ b(â)nana;

(3) flutuação na pronúncia entre ditongo/hiato, mio.lo mi.o.lo;

(4) vocalização da líquida lateral em final de palavra, /mal/ /maw/;

(5) pronúncia de outras consoantes em final de palavra, ma $(x) \sim \operatorname{ma}(R) \sim \operatorname{ma}(r)$, pat $\left.\int\right\} \sim p a(z)$ etc.;

(6) pronúncia da vibrante forte, $\left.\left.c a(x)_{0} \sim c a(\check{r})_{0} \sim c a t \gamma\right\}_{0} \sim c a(b)\right\}_{0} \sim c a[R]$ oetc.;

(7) casos de harmonia vocálica, stotar $\neq$ stu\} ar;

(8) casos de ligação de palavras, sá-la-már-gu, lú-za-zúl;

(9) casos de epêntese, adteevogado, abfi)ssoluto;

(10)casos de alternância vocálica verbo-nominal, s(i)rvis (2.a. pes. pl. de servir) e sterrvis (pl. de servil).

Problemas esses que são retomados na Fonêmica em termos de configuração da pauta tônica; neutralização; arquifonema; debordamento; juntura aberta; estrutura silábica.

\section{Problemas não-solucionados na descrição fonética}

\subsection{O timbre na distinção das vogais}

No Brasil, o vocalismo português erigido antes da análise proposta na Fonêmica (1953) mostrava-se bastante complexo por causa da diversidade de interpretação do papel do timbre, da articulação e da nasalidade para a

\footnotetext{
3 Os exemplos não se excluem, i.e. exemplos da NBP recorrem em Nascentes e em Oiticica. Por esta razão, a soma parcial das unidades de contagem ultrapassa o total.
} 
classificação das vogais átonas. O Quadro 1 sumariza a classificação das vogais encontrada no Anteprojeto (1937) que, embora discutida em plenárias do Congresso, não foi modificada para instituir as NBP. ${ }^{4}$

\begin{tabular}{|c|c|c|c|c|c|c|}
\hline \multirow[b]{4}{*}{ NBP } & \multicolumn{5}{|c|}{ TIMBRE } & \multirow[b]{3}{*}{ NASAL } \\
\hline & \multirow{2}{*}{$\begin{array}{c}\text { ABERTO } \\
\text { ORAL }\end{array}$} & \multicolumn{2}{|c|}{ FECHADO } & \multicolumn{2}{|c|}{ REDUZIDO/SURDO } & \\
\hline & & ORAL & NASAL & ORAL & NASAL & \\
\hline & $\mathrm{má}$ & & $\mathrm{r} \tilde{a}$ & $\mathrm{~d} a$ & & \\
\hline \multirow[t]{4}{*}{1938} & fé & ipê & vem & $\mathrm{d} e$ & então & \\
\hline & vil & cima & & & & vim \\
\hline & só & côr & som & ato & camondongo & \\
\hline & $\mathrm{sul}$ & tudo & & & & $\mathrm{r} u \mathrm{~m}$ \\
\hline
\end{tabular}

Quadro 1: Os 19 fones vocálicos no Anteprojeto (1937) nas NBP (1938)

Com base na fala carioca, o grupo de decisão do Congresso da Lingua Cantada operou uma síntese nos sons assim organizados e obteve, como resultado, valores médios para o vocalismo brasileiro: 19 fones vocálicos 12 vogais orais divididas quanto ao timbre (aberta, fechada e surda, isto é, reduzida) e 7 vogais nasais, 3 fechadas, 2 reduzidas e os segmentos representados por I ( vim) e U (rum), nem fechados, nem abertos, nem reduzidos. Embora não se tenha explicitado, parece que os autores das Normas levaram em conta, na classificação das vogais reduzidas, também a posição do segmento no interior da palavra: pois são sempre 'surdas' as vogais orais átonas finais e as nasais pretônicas. As NBP seguiram Nascentes, como se verá. ${ }^{5}$

Nascentes (1933: 24-5) obtivera as diferentes vozes orais a partir da diversidade de timbre no continuum sonoro. Sua classificação partiu do que

\footnotetext{
4 Embora idealizado e organizado por Mário de Andrade (1893-1945), o Anteprojeto de Língua Padrão (1937), foi revisto por Nascentes quanto à 'técnica fonética'. Também na primeira tentativa de estandardização da variante brasileira do português o foneticista exerceu esse papel de mentor (cf. França 2003).

5 Cf. Anais 1938: 54, O Idioma Nacional: Gramática Histórica (1933, Vol. IV) de Nascentes, destinado a estudantes do curso secundário, foi o modelo fundamental para o estabelecimento das NBP. As outras obras-fonte foram: O Linguajar Carioca em 1922 de Nascentes, Lições de Português (1934[1921]) de Sousa da Silveira, O Português do Brasil (1936) de Renato Mendonça, A Língua do Nordeste (1934) de Mario Marroquim e o Dialeto Caipira (1920) de Amadeu Amaral.
} 
considerava voz fundamental $a$ até as vozes extremas $i$ (aguda) e $u$ (grave), chegando a 9 fones, representados sobre um ângulo de $45^{\circ}$, (i-é-ê-e-a-óô-u-U), espécies essas multiplicadas em abertas ou baixas, fechadas ou altas e reduzidas. Segundo o autor, elevando-se o dorso da língua em sua metade anterior e abaixando na posterior, têm-se as vogais anteriores ou palatais e, inversamente, com o acréscimo do arredondamento dos lábios, as vogais posteriores ou velares. Em outras palavras, as vozes orais desdobram-se em uma escala de timbres crescentes (do som anterior mais fechado [i] para o mais aberto [a]) e decrescentes (do posterior [a] para o mais fechado [u]).

Para Oiticica, um dos motivos de controvérsia era justamente este:

A classificação das vozes em anteriores e posteriores, criação, suponho, de Rousselot, sempre me pareceu absurda. Dois caracteres podem ter a voz: sua articulação, i.e., a zona de interrupção da corrente expiratória, e a sua ressonância. O ã caracteriza-se por sua articulação zero, e sua ressonância nasal. O i tem articulação línguo-palatal e ressonância bucal. O õ tem articulação bilabial e ressonância nasal. A língua só entra

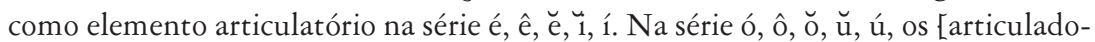
res] são os lábios. Em rigor, posso pronunciar a série ó...ú sem retrair a língua; mas é humanamente impossível pronunciá-la sem fechar os lábios. A retração da língua facilita, apenas, a ressonância. Em ambas as séries a ressonância é anterior à posição da língua. Logo, na série ó...ú, tanto a articulação como a ressonância são anteriores. Como, pois, chamar-lhes vozes posteriores, e, mais ainda, velares? Que tem o véu palatino com a série ó...ú? (Oiticica 1955[1938]: 172)

Ao contrário de Nascentes, para construir o seu "Sistema fonético brasileiro", Oiticica (1955 [1938]) tomou como elemento fixo (portanto, estável) a voz 'inarticulada' [ã], nasal, porque, na sua produção, haveria imobilidade dos órgãos fonadores, isto é, nenhum esforço ou movimento é feito, ou percebido. Havendo mobilidade, Oiticica determinava a contraparte oral, articulada: "impedida a ressonância nasal pela articulação do véu palatino com a parede da faringe nasal, dá-se a voz $a$, de ressonância bucal".

Percebe-se que Nascentes, ao postular uma voz fundamental a leva em conta o efeito acústico da ressonância percebida devido a modificações de volume no ressonador bucal (oral) e as diferentes aberturas ('timbre') das vogais são conseqüência do distanciamento variável dos articuladores envolvidos na sua produção, a língua e o céu da boca (volume maior, som mais grave; menor, som mais agudo); ao passo que Oiticica, ao postular o 
$\tilde{a}$ como voz inarticulada leva em conta principalmente a ressonância nas fossas nasais. Para Oiticica, a questão é mais de fisiologia do que de percepção física (acústico/auditiva).

É possível inferir onde se localiza a maior dificuldade de análise: a inexatidão do traço timbre, escalar, tomado como parâmetro básico para identificar os fones átonos, em posição final de sílaba e em posição final de palavra.

Nas NBP (1938:72) já se reconhecera a impossibilidade de estabelecer regras (regularidades), ou "mesmo denunciar tendências." Ainda assim, Nascentes continuou a usar esse parâmetro para classificar as vogais brasileiras, comparando-as com as portuguesas, na nova edição de $O$ Idioma Nacional (1937/1938), lançada meses após a realização do Congresso da Língua Cantada. Embora Nascentes admita que 'quase' não se percebe a diferença entre o $i$ aberto e o $i$ fechado, nem entre $u$ aberto e fechado: o $a$ de sofá é aberto, o de mesa é reduzido, o a fechado não temos (exemplar português, cada); o $i$ de anil, vil, viu é aberto, o de vi, mirada é fechado e o de tarde é reduzido; o $u$ de tuba é aberto, o de sul, tumba é fechado e o de punir, escápula, lado é reduzido, bem como purteiro na pronúncia portuguesa.

Consoante o ambiente fonético e a área regional, a multiplicidade e sutileza de timbres que as vogais inacentuadas apresentam era um dos problemas que mais embaraçava os descritores daquela época.

Não digo ilugíu como os portuguêses, nem èlogío como os nordestinos, nem êlogio como um rio-grandense, mas è logío. (Oiticica 1955[1938]: 176)

Fora justamente levando em conta as diferentes atualizações pretônicas em O Linguajar Carioca que Nascentes (1953 [1922]) elaborou a divisão das áreas lingüísticas regionais dos subfalares do Brasil, com diversidade de realização fonética porque de timbre mais aberto ou mais fechado (v. Callou e Leite 1990).

Se Nascentes entendia o timbre como resultado perceptual devido a diferenças articulatórias quanto a graus de apertura, ${ }^{6}$ Oiticica (1955[1916]: 35-36) entendia que o timbre da voz se altera de acordo com a ressonância

6 Cf. Mattoso Câmara 1956 e edições seguintes, isto significa 'abrimento', distância que pode ser nula (oclusão) entre os órgãos fonadores determinantes da articulação de uma forma fônica; corresponde ao francês 'aperture' e é diferente de 'abertura' da boca enquanto se fala, usado em fonética. 
em cada uma das cavidades produzidas no canal vocal, durante a fonação, funcionando, assim, como ressonador, ou, ainda, conforme a maior ou menor abertura da boca, quer dizer, afastamento das mandíbulas. Para ele, "temos a voz faríngea (gutural), a bucal (oral) e a nasal." Oiticica (1955 [1938]: 173) complementa seu ponto de vista: "o movimento da [língua] na série ó..ú não é articulação, é mera retração auxiliar para alongar o tubo sonoro."

Não vou tomar espelho para ver a abertura pois quando digo que a vogal é fechada, refiro-me ao timbre e não à abertura da boca e ainda mais, veja em Grammont (hoje não se dá mais um passo sem Grammont), tanto o $a$ oral como o nasal têm a mesma abertura. (Nascentes 1939[1938]: 122)

A Oiticica parece ter escapado a diferença entre 'abertura' e 'apertura', distinção articulatória que Nascentes levava em conta.

Por seu lado, Mattoso Câmara (1953b: 129) abandona 'timbre' como critério de classificação das vogais e retoma a questão em termos de pauta tônica. Nas suas palavras, "do ponto de vista da fonêmica, só interessa a circunstância de não haver traços distintivos”.

Mattoso Câmara (1953b:77, 80-81) afirma que a questão da distribuição alofônica das vogais é um dos problemas mais intrincados da fonêmica portuguesa no Brasil: na pronúncia coloquial frouxa e na língua familiar, o quadro fonêmico das vogais átonas não-finais funciona mal, embora subsistindo, em princípio, na pronúncia coloquial tensa. Em conseqüência do caráter átono e da debilidade maior ou menor da sílaba em que os segmentos se acham em relação à sílaba acentuada no vocábulo desaparecem certos contrastes, produzindo-se reduções no quadro de 7 fonemas vogais tônicos. Há neutralização das oposições quanto à elevação da língua (abrimento) nas vogais médias da pauta pretônica (entre vogal aberta e fechada /E/-/e/, /o/-/o/); há neutralização das oposições nas médias altas finais da pauta postônica (/e/ : /i/, /o/ : /u/) e, na pauta postônica em proparoxítonos, há neutralização da oposição na série posterior das átonas não-finais, enquanto na série anterior, /e/ mantém-se. Ainda, a vogal baixa anterior /a/ passa a posterior (costumeiramente dito fechado) no português brasileiro, alofone central posterior e 'abafado' diante de consoante nasal na sílaba seguinte, representado como /â/: amo, ano, anho. Por exemplo, br[a]mar, mas $b r$ [a]dar (1953: 70), diferentemente do português europeu em que há $[\mathrm{e}]$ nesse contexto. Mattoso estabelece, pois, dois quadros de 
vogais átonas, segundo a sua distribuição no conjunto vocábulo: um para as pretônicas e um para as postônicas em fim de vocábulo (afora aquele mais oscilante, para as postônicas de proparoxítonos).

Como vogais inacentuadas, as pretônicas médias estão sujeitas a harmonizar-se com o grau de abrimento da vogal alta acentuada que se lhes segue. Caso de overlapping fonológico, termo que Mattoso traduziu para 'debordamento', exemplificados por formas como c[o]mprido $\neq c[u]$ mprido, em que o fonema alto transpassa sobre a área do médio, particularmente na norma 'relaxada': p p $\mathrm{e}] \mathrm{ar} \neq \mathrm{p}[\mathrm{i}] \mathrm{ar}, \mathrm{s}[\mathrm{o}] \mathrm{ar} \neq \mathrm{s}[\mathrm{u}] \mathrm{ar}$ (debordamento do fonema médio e que pode ser ditongado $\left.\mathrm{p}\left[\mathrm{e}^{\mathrm{y}}\right] \mathrm{ar}, \mathrm{s}\left[\mathrm{O}^{\mathrm{w}}\right] \mathrm{ar}\right)$. Para Mattoso Câmara (1956), a língua portuguesa tem a tendência de harmonizar na escala dos abrimentos, e a atualização flutua de vogal média para alta e viceversa. O alteamento das pretônicas explica a pronúncia [mininu] e a grafia milhor (empregada por Mário de Andrade). Com efeito, exemplos como menino, perigo e feliz, mostram o desempenho vacilante do subsistema de cinco alofones vocálicos, quando entra em cena o subsistema de três alofones, similar àquele por certo aspecto. A ação da harmonização explica também o fato de

[...] vocábulos muito usuais fixa[re]m-se [...] sob esta forma alterada [...], em virtude de aparecerem preponderantemente na pronúncia coloquial frouxa ou na língua popular. [...] É a esta luz que se deve apreciar os contrastes corpinho /qorpi'nhu/ (pequeno corpo), vocábulo de derivação viva [isto é, ainda produtivo], e /qurpi'nhu/ (peça de vestuário), ou folbinha /folhi'nha/ (pequena folha), também derivado vivo, e /fulhinha/ (calendário), depreendidos por Souza da Silveira [...]. (Mattoso Câmara 1953b: 80, 81)

O olhar de Mattoso Câmara para além da diversidade aparente da fala o autorizou a postular o acento como o primeiro traço descritivo pertinente (um prosodema, no sentido de Trubetzkoy 1946[1939]), a partir do qual as vogais estruturam a sílaba portuguesa, e a construir os subsistemas vocálicos variantes, representados pelos símbolos entre barras oblíquas: o das tônicas, /i/ /e/ lè/ /a/ lò/ /o/ /u/; o das átonas não-finais, /i/ /e/ /a/ /o/ /u/ ; e o das átonas finais, /i/ /a/ /u/, além de duas assilábicas, as semivogais /y/ e/w/, alofones de natureza vocálica das altas /i/ e /u/, que formam ditongos em português. O Quadro 2 sintetiza o sistema fonológico proposto na Fonêmica (1953), no âmbito do vocalismo. 


\begin{tabular}{|l|c|c|c|c|c|c|c|}
\hline TÔNICA & $\mathrm{i}$ & $\varepsilon$ & $\mathrm{e}$ & $\mathrm{a}$ & 0 & $\mathrm{o}$ & $\mathrm{u}$ \\
\hline NÃO-TÔNICA & $\mathrm{i}$ & \multicolumn{2}{|c|}{$\mathrm{e}$} & $\mathrm{a}$ & \multicolumn{2}{|c|}{$\mathrm{o}$} & $\mathrm{u}$ \\
\hline NÃO-TÔNICA FINAL & \multicolumn{2}{|c|}{$\mathrm{i}$} & $\mathrm{a}$ & \multicolumn{3}{|c|}{$\mathrm{u}$} \\
\hline
\end{tabular}

Quadro 2: O sistema vocálico do português brasileiro

Como resultado da adoção dessa postura teórico-metodológica e da aplicação do conceito operatório 'neutralização', Mattoso Câmara (1953b:77) obteve o sistema de fonemas vocálicos, no qual estruturou as vogais em um triângulo de relações opositivas com 7 vogais tônicas e dois triângulos para as vogais átonas: um, com 5 vogais átonas não-finais e o outro, em que se distribuem 3 átonas finais.

É aqui que se demonstra a ruptura de Mattoso Câmara com a tradição de pesquisa fonética de então: nesta, os fones vocálicos são classificados isoladamente quanto ao timbre (aberto/fechado/reduzido) e quanto ao estado do véu palatino (oral/nasal); já o ponto de partida para a proposição de fonemas do sistema vocálico é a oposição 'presença de tonicidade' versus 'ausência de tonicidade', acrescido do fato de serem ou não bases de sílaba.

\subsection{O problema do ditongo/ hiato oscilante}

Encontrar uma regra para estabelecer a diferença entre ditongo, hiato e tritongo era uma querela antiga, generalizada (cf. Revista de Filologia Portuguesa 1924). De acordo com Oiticica (1955[1916]: 49), não havia consenso entre os gramáticos sobre o número dos ditongos, tampouco a existência e número dos tritongos em português, mostrando "quão longe estamos da solução científica do problema." Em 1924, Nascentes negara a existência do tritongo e afirmara que havia apenas um elemento vocálico na sílaba e o outro elemento, consonantal. Novamente, Oiticica contestou.

Bem diz Nascentes que o problema não é de filologia portuguêsa, mas de fonética fisiológica, isto é, pura fisiologia. (Oiticica 1955[1924]: 149).

Fundamentado em sua teoria dos encontros vocálicos, Oiticica (1955[1916]; 1955[1938]) sustentou que havia duas vozes no ditongo em geral, mas em exemplos como tua, o segmento $w$ era de natureza consonantal, uma fricativa bilabial porque impossível pronunciá-lo sem fe- 
char os lábios: "Em glória e rósea, sobretudo no segundo, só pode haver ditongo em poesia. Na prosa culta, padrão, devem soar trissílabos, [como] em cárie, sério, névoa, etc."

Para Nascentes (1937/1938), na pronúncia de hiatos começados por $i$, $o$, ou $u$ tônicos havia a intercalação de outro $i$ antes da segunda vogal: "tio soa como se fosse ti-io; [idem] Lisbou-ua, vou-uo [e] tua soa como se fosse tu-ua."

Em seus termos, Oiticica não conseguira 'ver' o mesmo encontro vocálico em níveo e alívio, posição assumida por Nascentes. Para Oiticica, na prosa, níveo é hiato, no entanto, poderia ditongar-se na poesia. Ao passo que alívio apresenta ditongação real na prosa e obrigatória no verso. Por isso, dizia o autor na carta de 1938, não haveria a possibilidade de grafar nivio, foneticamente.

De um lado, deve-se lembrar o contexto das contendas ortográficas, que permearam a primeira metade do século XX. De outro lado, observa-se que estava em jogo a interpretação da estrutura da sílaba. É importante notar, a seguir, o material privilegiado para a observação da prosódia brasileira: o texto poético, com a métrica indicando a pronúncia normal, espontânea, fato especialmente aproveitado na terceira parte da Fonêmica (1953).

Na interpretação de Nascentes, ei em cheio era ditongo; na interpretação de Oiticica (1955[1938]: 179-180) a divisão fonética não poderia ser chei-o, e sim, che-io: "forma sílaba com o $o$ e, não, com o e", também nesse caso o semi-segmento também era consonantal, $i$ línguo-alveolar. Como Oiticica costumava escrever no Correio da Manhã artigos sobre versificação, condenando especialmente o 'hiatismo' e o 'ditonguismo' praticados por certos poetas (cf., por exemplo, a edição de 19 de setembro de 1917), ao responder-lhe, Nascentes não perdeu a oportunidade que seu opositor lhe dava graciosamente.

Pois olhe: poetas, e poetas de ouvido delicadissimo como o seu querido Hermes da Fonseca, Francisca Julia, Bilac (j'en passe...) viram. Quer ver? [U]m exemplo de Bilac que vem a talho de foice:

Viuva triste, que à paz do claustro te pede alivio

Branca, sob o livor do escapulario niveo,

"A um violinista"

Tempo virá em que o preconceito dos eruditos terá de curvar-se diante da realidade e se escreva nivio em vez de niveo. Continua V. a achar que no ditongo ha duas vogais; 
eu continuo a achar [...] uma e hoje nem se admite mais a segunda como semi-vogal; o ditongo é uma vogal longa que muda de timbre no curso de sua emissão. [Tais] ditongos $(i a, u a)$ são instaveis [...]. Mantenha V. a sua definição de ditongo; eu conservo meu modo de ver. (Nascentes 1939[1938]: 127)

É sabido que Nascentes sempre clamou pela instalação de laboratórios de fonética no Brasil. Essa era uma das razões pela qual ele procurava acompanhar de perto a literatura, publicada em Portugal, sobre os últimos resultados obtidos a partir da técnica experimental. Na sua resposta para Oiticica, Nascentes (1939[1938]) informou que, diferentemente do $i$ observado na escrita da palavra cheio, por essa técnica rigorosa, era possível visualizar "um desdobramento": na verdade, a parte semivogal tem lugar na primeira sílaba e a parte semiconsoante ocupa a segunda sílaba, chei-yo.

Outra vez, Mattoso Câmara (1953b:38, 67, 124) retomou a questão demonstrando que, na atualização da fala, os fonemas vogais e consoantes funcionam combinados em uma unidade maior, a sílaba. Foi assim que o autor resolveu o problema da oscilação na pronúncia entre ditongo fonético e hiato fonético, exemplo de liberdade de variação na pronúncia, porque não têm valor distintivo. Nesse plano prosódico, o fonema, embora definido como feixe de traços, é indivisível, porque constituinte imediato de uma unidade maior - a sílaba. O acento de intensidade opera sobre grupos de fonemas que constituem essa unidade fonológica. Sua presença ou ausência e variabilidade incide sobre determinado constituinte dessa unidade - o núcleo da sílaba. Esse lugar prosódico é ocupado em português sempre por uma vogal, por isso, dita silábica. Por oposição, a consoante pode ocupar suas margens crescente e/ou decrescente (ápice/declive, direita/esquerda).

Mattoso chegou a um problema no exame da estrutura da sílaba portuguesa, que envolve algumas questões controvertidas: existem, fonemicamente, ditongos? Quer dizer, na emissão una da sílaba, as vogais altas das séries anterior e posterior juntar-se-iam a uma vogal vizinha, tornandose, por isso, assilábicas? Ainda, essa vogal 'auxiliar' teria uma natureza consonantal, ou vocálica? Ocupa um lugar periférico na sílaba, ou compartilha o lugar nuclear com o segmento silábico?

O semiditongo foi definido por Mattoso (1956) como um ditongo em que não há propriamente uma vogal assilábica, mas uma vogal longa, cujo abrimento é menor no início ou no fim da sua prolação (ex.: feet). Em 
português, muitos gramáticos empregavam o termo semiditongo para o ditongo imperfeito, isto é, ditongos crescentes átonos em finais de vocábulo, como níveo, alívio, réstia, tênue e mágoa, formas que tanto preocuparam Nascentes e Oiticica. Um, advogando o comportamento de ditongo e outro advogando, ora pelo comportamento de hiato, ora pela ditongação prescritiva.

Para Mattoso Câmara (1953b: 75), não é que, foneticamente, não haja semiditongos: "Um/y/ e um /w/ consonânticos aparecem como fatos mecânicos [isto é, automáticos] de juntura para desfazer hiatos”, pois era assim que esses elementos eram tratados na métrica. No uso dos poetas brasileiros, comprovava-se a ditongação na pronúncia normal espontânea: rima-se indiferentemente moléstias com veste-as e résteas (cf. Mattoso Câmara 1953b: 134, a grafia de réstias é a do poeta Hermes Fontes). Nesse mesmo tipo de natureza consonântica, Mattoso Câmara (1953b:75) incluiu a assilábica, cuja realização apresenta uma nasal em posição tônica final de palavra: "Temos analogamente um /y/ dêste tipo como parte final de um -em /ê/ final (também, além, etc.). Não se trata, porém, de elementos fonêmicos, e o semi[di]tongo não passa da realização fonética de uma vogal simples nessas posições determinadas". Uma ditongação fonética, portanto.

Comentando a natureza CV do glide, Mattoso Câmara (1953b:72) concordou com os dois opositores quanto à natureza consonântica dessas assilábicas, mas apoiou a interpretação de Nascentes: na perspectiva fonética, em cheio a pronúncia é /xeiyu/, bem como/tuwa/, "o que é exato do ponto de vista naturalista, mas fonemicamente irrelevante", porque não têm valor distintivo. Portanto, glides não são fonêmicos. Orientando-se pelos moldes estruturais da língua na perspectiva fonêmica, Mattoso Câmara (1954a:58) interpretou cei-a, bói-a, assim, também chei-o: "Na realidade fonética há $[\ldots .$.$] a rigor uma dupla ditongação (ditongo decrescente e$ seguido de ditongo crescente -/sei-ya/, /boi-ya/), como ressalta Nascentes."

Em 1953, Mattoso usou o exemplo cheio como argumento para demonstrar que estavam separadas as metodologias das duas disciplinas: de um lado, a da Fonética e, de outro lado, a da Fonêmica.

Do ponto de vista fonético, o tratamento é dado em termos da diferença de som entre assilábico e silábico correspondente. Do ponto de vista fonêmico, e de acordo com Mattoso Câmara (1953b: 73, 136), "ao contrá- 
rio, os assilábicos podem ser os mesmos fonemas que as vogais silábicas respectivas, embora acùsticamente muito diversos, porque variantes posicionais em distribuição complementar." Desse modo, os assilábicos que arquitetam ditongos verdadeiramente fonêmicos são aqueles que contrastam com vogal simples porque há oposição distintiva na significação das formas -pá: pai-pau, lêe : lei-leu, dó : dói, cal : qual, mó : mói, ré : réu, sê : seu, vi : viu.

Disso se pode inferir que é o núcleo composto de duas vogais (VV) que contrasta com o núcleo simples $(\mathrm{V})$ e não, um núcleo de vogal + consoante $(\mathrm{VC})-$ ['maw $]$ : ['ma $]-$, mas não é ['maw $]$ que se opõe a ['maR].

Ainda segundo o lingüista, o caráter do ditongo em português é polifonemático, ou seja, apresenta um tipo de sílaba com núcleo complexo. Como se sabe, um centro de sílaba polifonemático pode ser composto por duas vogais (VV), ou por uma vogal e uma consoante (VC), sendo C apenas as outras soantes, nasais e líquidas (cf. Trubetzkoy 1946[1939]: 196), o que, por conseqüência, determina a feição da sílaba, respectivamente, livre (aberta) ou travada (fechada). Nesse caso, as semivogais [j] ou [w], seguindo uma vogal silábica acentuada, seriam variantes contextuais ou posicionais (alofones) dos fonemas [i] e [u] daquele quadro tônico de 7 vogais orais. Em outras palavras, quando se junta a uma vogal do sistema de 7 fonemas vocálicos acentuados uma das vogais altas inacentuadas, há oposição quanto à significação e, portanto, os ditongos decrescentes são ditos verdadeiros, isto é, fonêmicos. Na visão de Mattoso, essa seria a razão pela qual as duas vogais assilábicas estão em distribuição complementar com as vogais silábicas: [j] e [w] sempre ocorrem em determinado contexto (núcleo de sílaba polifonemático, após vogal silábica, tônica) e /i/ e /u/ (vogais silábicas tônicas) sempre ocorrem nos demais ambientes, que não os de suas contrapartes foneticamente semelhantes, as quais funcionam apenas como auxiliares na formação do ditongo.

Consta da Fonêmica um argumento a favor dessa interpretação, isto é, de que a natureza das assilábicas [j] e [w] é vocálica, e evidencia que há dois elementos V ligados ao núcleo: a facilidade, usual, da passagem de /y/ assilábico em papai para [e] silábico. Outro argumento encontra-se nos seguintes dados lingüísticos, exemplos usuais de ditongação e monotongação alternadas, em registros diversos: peixe pexe, baixo baxo, feichar $\sim$ fechar, meixer mexer. Assim, "justifica-se tratá-lo fonêmicamente como 
vogal assilábica, no quadro das vogais portuguesas" (Mattoso Câmara 1953b: 68).

Entretanto, surpreendentemente, quando acabara de afirmar que [y] e [w] eram os mesmos fonemas /i/ e /u/ em distribuição complementar, Mattoso Câmara (1953b: 73) assevera, no mesmo parágrafo, o contrário. As assilábicas $[\mathrm{y}]$ e [w] pertinentes à disciplina Fonêmica podiam não ser os mesmos fonemas que as vogais silábicas correspondentes.

Seria o caráter oscilante da arquitetura própria (inerente) dos ditongos portugueses, ou alguma indecisão, ambivalente, do descritor?7 Qual a motivação para essa mudança de atitude?

Com efeito, na discussão desse problema, parece haver uma ambivalência na descrição dos dados. Costuma-se dizer que a posição de Mattoso era, de início, considerar as assilábicas $[j]$ e $[w]$ como consoantes e que, posteriormente, essa posição foi revista por ele (cf. Cristófaro Silva 2001). Mas, constatei que considerar a assilábica como vogal já estava na Fonêmica de 1953.

Pondo de parte a diferença acústica, a vogal assilábica pode não ser o mesmo fonema que a vogal silábica correspondente se houver no léxico da língua em questão uma oposição distintiva entre elas. Para Mattoso Câmara (1953b: 73), este é o caso de pares como vou/vow/ : vôo /vou/, sois /soys/ : soes /sois/. Os segundos membros de cada par apresentam "um /i/ ou um /u/ silábicos na qualidade de arquifonemas em posição final nas séries /è-e-i/ e /ò-o-u/, respectivamente, [...] em contraste com os assilábicos /y/ e /w/ do primeiro membro", do mesmo modo que a posição silábica ou assilábica distingue prosodicamente "formas vocabulares unas de outras verbais a que está enclítico o pronome átono o-os: viu /viw/ : vi-o /viu/, deu /dew/ : dê-o/deu/ [...] ou deus /dews/ : dê-os /deus/." 8

\footnotetext{
Cf. Mattoso Câmara 1976[1970]: 36, na Estrutura da Lingua Portuguesa, encontra-se: "interpretar a vogal assilábica, mesmo em termos fonêmicos, como vogal (alofone assilábico de uma vogal, e, nunca como uma consoante)"; nos Problemas de Lingüística Descritiva 1981[1969]: 30, "há 4 modalidades de sílaba travada em português: $\mathrm{V} / \mathrm{z} /, \mathrm{V} / \mathrm{r} /, \mathrm{V} / \mathrm{l} /$, que desaparece com a vocalização do /1/ para /w/, e V/y,w/ (ditongos decrescentes). Pode-se acrescentar um quinto tipo, V/N/..." (v. também Collinschonn 1996).

8 Do estudo prosódico de Mattoso resultou não só a noção de 'vocábulo fonológico' (individualizado pelo acento; todo vocábulo como forma 'livre' tem um acento), mas também a noção de clítico como forma 'dependente', porque lhe falta essa caracterização acentual que lhe daria individualidade em uma seqüência proferida (embora essa noção não esteja explicitada na Fonêmica de 1953; v. Mattoso Câmara 1981[1969], 1976[1970] e 1972, entre os textos publicados).
} 
Não levar em conta a diferença acústica significa que a definição da natureza do glide como $\mathrm{C}$ ou $\mathrm{V}$ não depende do conjunto de traços que os caracteriza (não fica resolvido o problema da natureza vocálica ou consonântica das assilábicas portuguesas, posto de lado). Como Mattoso não representou a fronteira silábica, nem o acento nesse tipo de exemplo, ${ }^{9}$ poder-se-ia pensar em /vow/ e /soys/, pronunciados monossílabos, e /vo.u/ e /so.is/, pronunciados dissílabos. Nesse caso, o que estaria em jogo seria o critério da correlação de silabificação (Trubetzkoy 1946[1939]:199, 200). Nessa posição fônica, em que a presença de /y/ exclui a de /i/ e o mesmo para /w/ e /u/, a oposição distintiva é substituída pela oposição de silabificação e deve-se considerar os elementos em questão como dois fonemas diferentes. ${ }^{10}$ Então, em formas como ['so's] e ['sois] esses significantes divergem. Por outro lado, poder-se-ia pensar, ainda, na definição que o fonologista deu para vogal como forma livre (porque pode funcionar só, na sílaba e no enunciado) e associar a [j] e [w] o caráter de formas dependentes (para existir, um e outro precisam da vogal silábica correspondente e daí, funcionar como assilábicos). Na verdade, o critério distributivo é que foi usado: significantes que aparecem em posição de núcleo silábico, significantes que aparecem antes de núcleo e assim por diante. É esse critério que está em jogo, mas não exatamente tal como Bloomfield (1933) o fez para o inglês, cuja análise foi inteiramente baseada no método distributivo, mas sim, posição de núcleo versus posição de não-núcleo e o traço comum que une os elementos da correlação em formas como ['vow'] e ['vou] e ['so's] e ['sois] é o acento.

Seguindo as palavras de Mattoso, um outro tipo de contraste, na base do qual estabeleceu os arquifonemas das séries anterior e posterior, foi verificado em formas como viu/viw/: vi-o/viu/, deu/dew/ : dê-o /deu/, deus /dews/ : dêe-os /deus/; todos os segundos membros do par pertencem ao domínio da palavra fonológica (ou grupo clítico). Trata-se de casos de juntura ou sândi, nos quais se observa a função delimitativa do acento conforme a sua posição variável na sílaba de determinado grupo fônico. Isso pode ser um indício de que Mattoso Câmara continuava no plano das características prosódicas, segundo a classificação das particularidades fônicas distintivas elaborada por Trubetzkoy (1946[1939]: 196 ss).

9 Em todos os monossílabos tônicos o acento não foi representado.

10 O contexto da exposição de Trubetzkoy diz respeito ao búlgaro, não ao português. 
O lugar de onde Mattoso observou os dados vocálicos foi a pauta prosódica, na qual o acento por sua característica hierárquica em português tem a capacidade não só de discriminar vocábulos diferenciados pelo significado, mas também a capacidade de delimitar seqüências homofônicas, no caso, na pronúncia normal da fala carioca. Nessa norma culta espontânea, ['vow] e ['vou $]$ são atualizados prosodicamente unos e a diferença entre eles é formal por um lado, e por outro lado, localiza-se na combinação dos respectivos significantes. Do mesmo modo que o único tipo de ditongo cres-

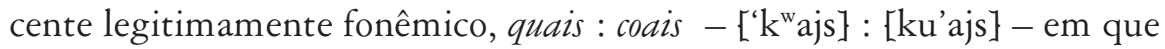
a uma consoante oclusiva posterior velar segue-se uma vogal posterior alta em sílaba acentuada. Esse par apresenta igualmente divergência formal e de configuração sintagmática com a mesma oposição de silabificação.

As vogais assilábicas, que assim temos de deduzir como fonemas, formam com a silábica um centro de sílaba polifonemático em regra como ditongo decrescente, pois os ditongos crescentes se desfazem em hiatos sem qualquer valor distintivo (fiel, miolo, suar etc.), salvo se se tem um /w/ com /q/ ou /g/ pré-vocálico (cf. quais /qways/ e coais na pronúncia corrente /quays/, ou acuais /aquays/). (Mattoso Câmara 1953b: 75)

Fonemicamente, o que os exemplos ['vow] : ['vou ] e ['k'ais] : [ko'ais] têm em comum diz respeito à função delimitativa desempenhada na fonologia portuguesa por uma diferença na combinação de elementos em uma certa unidade prosódica, mesmo papel desempenhado pela hierarquia acentual, na qual os acentos tônico e subtônico indicam quantos vocábulos há em determinada seqüência proferida, isto é, em outra unidade prosódica. Quanto à oposição, é de silabificação, conforme, aliás, Trubetzkoy.

A partir do critério silábico versus não silábico, Mattoso Câmara confirmava, por exemplo, o estabelecimento do arquifonema /I/ nas formas verbais com vogal contígua acentuada, nas quais a oposição distintiva /y/ /i/ é anulada.

São ainda distinções de ordem gramatical as que decorrem do contraste entre formas verbais de radical terminado em /u/, quando se lhe segue na desinência um /i/ silábico ou um /i/ assilábico: êste indica presente do indicativo da $3 .{ }^{a}$ conjugação (estatui, possui, influi, rui); e aquêle, presente do subjuntivo da $1 .{ }^{a}$ como arquifonema vocálico de posição átona final, grafado -e (acentue, sue, arrue). [...] É esta distinção que Alberto de Oliveira anulou, rimando azuis com flutues. (Mattoso Câmara 1953b: 74)

Do ponto de vista fonêmico houve neutralização, do ponto de vista fonético há ditongo, pois o hiato dissolve-se. A evidência empírica veio do 
exame da variação possível, tendo como material a poética brasileira, nesse caso, retirada de seu estudo sobre a estilística fônica (Mattoso Câmara 1953a: 38).

Sendo assim, é possível perceber que, na análise dos dados, não só a oposição distintiva, paradigmática, mas também o contraste delimitativo, sintagmático - um procedimento na pauta prosódica para a individuação vocabular -, serviram de procedimentos de descoberta em busca de evidências lingüísticas, para isolar os fonemas vocálicos e estabelecer seus alofones e arquifonemas.

Fonemicamente legítimos há 11 ditongos decrescentes orais, que podem vir a ser 10 em algumas regiões brasileiras: pai, pau, réis, réu, sei, seu, viu, dói, foi, vou, fui, todos acentuados, pois é o acento que lhes dá estabilidade. Em princípio, poderia haver ditongos desse tipo para todas as vogais do sistema que funciona inteiro, o do triângulo de 7 vogais tônicas orais. As restrições ficam por conta das regras de crase, elisão, ditongação e juntura, algumas das quais carreiam também informações morfológicas. $\mathrm{Na}$ descrição de Mattoso Câmara de 1953b, essas regras impedem que ocorram /iy/ e /uw/ e, na variante carioca do português, /ow/ monotongase /o/. Essa monotongação, regularmente observada, deve ter sido a razão pela qual o exemplo Lisbou-ua de Nascentes não foi reaproveitado na Fonêmica, mas vôo o foi, embora estivessem listados juntos n' O Idioma Nacional.

Não tratei do caso do vau (pessoa, Lisboa), rimando com amou-a por exemplo, porque, ao contrário do ditongo /ey/, o ditongo /ow/ já não é distintivo em português; a distinção entre /o/ e /ow/ é apenas estilística - parece-me -, como comentei de espaço na Contribuição à Estilística Portuguêsa. (Mattoso Câmara 1954b:54).

O número de ditongos fonêmicos aumenta com o considerar casos de vocalização de [1] posvocálico. (Mais tarde, Mattoso Câmara (1981[1969], 1976[1970]) acrescentaria também /'o w/ e /'uw/ pelo mesmo processo de vocalização em algumas realizações, como sol e sul).

Uma velarização excessiva do /l/ pós-vocálico, dando-lhe o efeito de uma semivogal /w/, [...] confunde formas como /mal/ e /maw/, /al'tu/ e /au'tu/, /vil/ e /viw/ etc. [...] A norma culta espontânea, ou variedade coloquial tensa, estabelece neste caso uma variante posicional /1/, velar, [com] articulação posterior bucal. [...] Ora, a variedade locucional [...] relaxada anula essa oposição depois de /a/ ou vogal anterior. Como depois de vogal posterior não aparece /w/ (pois /ow/ confunde-se com /o/ e /uw/ e /òw/ não constam do vocabulário português), /w/ e /l/ velar passam a constituir uma 
distribuição complementar de /1/ em posição pós-vocálica, conforme a vogal precedente seja respectivamente anterior ou posterior. (Mattoso Câmara 1953b: 33, 57-58)

Assilábicos que podem aparecer em fronteiras de sílabas, os ditongos crescentes devem ser separados dos verdadeiros ditongos fonêmicos porque, nesse sentido, são falsos. A qualidade das vogais assilábicas desses ditongos ilegítimos pode ser prevista pelo contexto fonético em que elas se acham: [j] ocorrerá depois de vogal anterior e [w] ocorrerá depois de posterior. Como, na visão de Mattoso, só existem 'coisas' que entram em alguma relação opositiva com outras 'coisas', esse tipo de ditongo não poderia ser fonêmico. Os ditongos crescentes são fonéticos. São formas particularmente oscilantes, pois dão liberdade de pronunciá-las também como hiato. As assim chamadas sinéreses (ditongação fonética), que a métrica nos versos dos poetas mostram, apontam para variações sincrônicas, ou seja, são exemplares de variação livre. Do mesmo modo, as diéreses (hiatização fonética), observadas nas rimas em sílabas poéticas, nada mais são do que liberdade de variação. Como a pronúncia normal do falar carioca oscila e não se observa um uso constante, Mattoso Câmara (1953b: 74) propôs uma solução para o problema dessa flutuação: a diferença entre ditongo e hiato em sílaba átona não é fonêmica porque não tem valor distintivo. $\mathrm{Na}$ sua visão, a exceção fica por conta de derivados de outros vocábulos, nos quais /i/ ou /u/ era silábico e tônico (traiçãa, saimento, abaulado), embora haja uma tendência na direção da livre variação.

Estou de acordo com o hiato em saimento, mas não em traição, nem em abaulado. (Nascentes 1949).

Há, ainda, um tipo de ditongo nasal fonêmico, decorrente da solução do problema das vogais ditas nasais que, como se sabe, foram eliminadas das considerações fonêmicas por Mattoso Câmara. Diferentemente do que alegava a tradição de pesquisa fonética, não existem vogais nasais em português, como fonemas distintos. Há uma vogal oral seguida de um arquifonema nasal que trava a sílaba.

A questão foi dividida em casos de nasalidade fonética (em cama e banana, por exemplo, há antecipação da nasal da sílaba seguinte, ou seja, nasalização automática por assimilação sem travamento consonântico, logo, variação livre) e casos de nasalidade fonêmica, $\mathrm{V}$ com nasalidade de travamento, em que há oposição VN : V, campo : capo (cf. Leite 1986, Bisol 1996, França 2003, que revisitam a tese da nasal fonêmica de Mattoso Câmara e, também, a tese da vibrante única). 
Ao interpretar a nasalidade fonêmica como um grupo de vogal oral mais elemento consonântico nasal em sílaba travada, como se fosse uma consoante pós-vocálica, Mattoso Câmara (1953b: 157) pôde estabelecer as contrapartes de [aI], [au], [oI], [uI] : ditongo + arquifonema nasal (VVN),

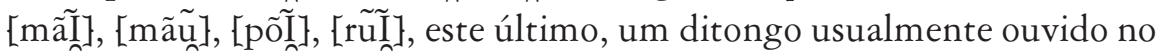
falar carioca. Observa-se apenas hiato fonético nas regiões (e/ou classes sociais) em que ruim é pronunciado dissílabo.

Assim, Mattoso Câmara resolveu o problema da oscilação na pronúncia entre ditongo fonético e hiato fonético. Distinguiu dois tipos de ditongos: um de caráter fonético, glide, e o outro de caráter fonêmico, ao examinar a estrutura da sílaba portuguesa, cujo núcleo é polifonemático, isto é, cada vogal assilábica, [j] e [w], compartilha o lugar nuclear na sílaba com o segmento silábico.

\section{Considerações finais}

Enquanto a descrição fonética contida nas Normas (1938) visava a estandardização do uso da língua falada no Brasil, a descrição fonêmica (1953) buscava as regularidades (regras) que estruturam esse uso em um sistema lingüístico, fonológico.

Os foneticistas da comunidade intelectual brasileira tinham como preocupações não só o problema da distância entre o português europeu e o português americano, mas também o da variação das pronúncias nos diferentes dialetos regionais e sociais do país, cujos fatos já haviam sido descritos por dialetólogos, a partir da década de 20. Eles se observaram, ainda, a questão da distância entre a língua falada e sua representação escrita (algumas vezes, as confundindo) e o modo como isso se realizava na língua poética. Continuaram a dedicar atenção às peculiaridades dos diversificados falares nacionais, o que levou, quase naturalmente, ao problema da descrição da variante preferida como língua padrão do Brasil.

Porém, no que diz respeito ao primeiro caso focalizado aqui, a descrição das vogais reduzidas não era segura e carecia de exatidão - 'tem som aproximado de', 'é quase pronunciado como'.

Por meio dos conceitos de fonema, de neutralização e de variante de três ordens diversas (posicional ou combinatória, livre e estilística ou indi- 
vidual), Mattoso Câmara enfrentou o problema descritivo das vogais em português na pauta prosódica com base na oposição do acento hierarquizável [ intensidade] e na sua configuração na sílaba em relação à vogal que porta o traço [+intensidade] no interior da palavra. Com isso, Mattoso abandonou o uso do parâmetro 'timbre'11 e resolveu a questão da multiplicidade de fones levantados, conseqüentemente, o problema das vogais reduzidas deixou de existir.

Ao optar pelo tratamento fonológico, o lingüista pôde notar que o fato de as vogais se diferenciarem pelo timbre decorria do acento. Sendo assim, esse foi o ponto de onde Mattoso partiu para construir o sistema fonológico das 7 vogais tônicas e dele deduzir os subsistemas das átonas, porque certas oposições deixam de funcionar, sem valor distintivo.

Partindo também das vogais acentuadas, com o auxílio dos conceitos de neutralização (fonológico, caso se queira associá-lo à Fonologia de Praga) e de debordamento ou overlapping (fonêmico, caso se queira associá-lo à metodologia distribucionalista), outros problemas também se resolveram. Entre eles, o segundo caso destacado neste trabalho: o problema da pronúncia flutuante entre ditongo e hiato.

Na questão do falso ditongo grafado -em, como também e além, Mattoso verificou que, em posição final tônica, a nasal se ditonga automaticamente, portanto, é variante posicional, ao contrário dos ditongos verdadeiros - $\tilde{a} 0$, - $\tilde{a} e$ em contraste com - $\tilde{a}$ e -õe com -om, esses sim, ditongos nasais verdadeiramente fonêmicos porque a base e a semivogal não são homorgânicas. Na cadeia da fala, Mattoso observou que as vogais e consoantes funcionam combinadas em uma unidade maior, a sílaba. Foi nesse domínio que o autor resolveu o problema da oscilação na pronúncia entre ditongo fonético e hiato fonético, exemplo de liberdade de variação porque não tem valor distintivo.

É impossível a comparação do Quadro 1, relativo à classificação das vogais na perspectiva da fonética, com o Quadro 2, relativo à estruturação do sistema de fonemas vocálicos na perspectiva fonêmica, pois não têm medida comum um com o outro. $O$ fato de que eles não podem ser avaliados em razão de sua ordem de grandeza demonstra a ruptura teórico-

11 Cf. Mattoso Câmara 1960, iniciado no Brasil por Franco de Sá 1915. 
metodológica de Mattoso Câmara com a antiga tradição fonética de análise da língua portuguesa: o estruturalismo aparece no Brasil quando a concepção concreta ‘de som’ foi substituída por um construto abstrato.

No que diz respeito ao objeto de estudo, a atitude dos foneticistas brasileiros era, nos termos de Trubetzkoy, atomista. Para aceitar o ponto de vista fonológico, era preciso escolher outra tradição de pesquisa, integradora, estrutural, que concebe a língua como um sistema de relações hierarquicamente organizado. No contexto intelectual brasileiro, a prática de análise verificada nos anos trinta e a prática de análise em 1953 construíram o problema da diversidade de pronúncia de modos diferentes e o resolveram com métodos estanques, incompatíveis e excludentes.

Com efeito, naquele momento, as duas perspectivas de estudo não poderiam ter sido vistas como complementares. Para a comunidade acadêmica brasileira, esse parece ter sido o fator fundador a distinguir naquele momento os dois métodos de descrição, o fonético e o fonológico (ou fonêmico, na metalinguagem de Mattoso Câmara). Desse modo, ambos os níveis de descrição lingüística, o nível fonético e o nível fonológico, submetiam-se a um padrão constante e abstrato composto de regularidades variáveis que poderia e deveria ser divisado e demonstrado pelo lingüista. A introdução do ponto de vista fonológico, em 1953, na descrição da variante brasileira do português trouxe, como conseqüência, a possibilidade de ultrapassar não só a diversidade manifestada e percebida na superfície concreta da fala corrente atualizada, mas também a diversidade da 'norma normal' ou 'normas sociais' (como definiu Coseriu 1980[1952]), nível de abstração intermediário.

Os resultados mostraram que Mattoso Câmara estava familiarizado com os problemas não resolvidos e com as soluções insatisfatórias dadas pelo modelo da Fonética clássica para a descrição do sistema fonético/fonológico. Enfrentou essas questões com o instrumental fornecido pelo método estruturalista e funcionalista para a descrição da variante brasileira do português. Escolheu e filiou-se à tradição de pesquisa fonológica universalista para descrever seu objeto material pelo alto grau de efetividade que esse tratamento oferecia para a resolução desses problemas específicos. A continuidade entre a tradição de pesquisa fonética e a linha de pesquisa que a Fonêmica de 1953 inaugurou no contexto acadêmico brasileiro verifica-se quanto a esses problemas compartilhados, porque pertencem ao ní- 
vel de análise fonético-fonológico e que só poderiam ser vistos como complementares se a concepção do objeto fosse a visão de língua como sistema, de sistemas. Nesse sentido, o tipo de descrição elaborada por Mattoso Câmara foi a que envolveu a depreensão da estrutura de uma língua particular e a explicação das relações que aí se estabelecem, no caso, a partir da norma carioca do português brasileiro.

E-mail: amfranca@usp.br

\section{REFERÊNCIAS}

Affonso, Ruy. 1958. Padronização da Prosódia Brasileira. In: Anais do Primeiro Congresso Brasileiro de Língua Falada no Teatro, 123-144. Rio de Janeiro: MEC.

Altman, Cristina. 1998. A Pesquisa Lingüística no Brasil (1968-1988). São Paulo: Humanitas.

Amaral, Amadeu. 1920. Dialecto Caipira. São Paulo: O Livro.

Anais do Primeiro Congresso da Língua Nacional Cantada 1938. São Paulo: Departamento de Cultura da Municipalidade de São Paulo.

Anteprojeto da Língua Padrão. Apresentado pelo Departamento da Municipalidade de São Paulo ao Congresso da Língua Nacional Cantada, 1937. São Paulo: Departamento de Cultura.

Bisol, Leda. 1996. Mattoso Câmara: uma Presença da Fonologia do Português. Estudos Lingüísticos, 25: 20-27.

Bloomfield, Leonard. 1933. Language. New York: H. Holt.

Callou, Dinah \& Yonne Leite. 1990. Iniciação à Fonética e a Fonologia. Rio de Janeiro: Zahar.

Collinschonn, Gisela. 1996. A Sílaba em Português. In: Leda Bisol (org.). Introdução a Estudos de Fonologia do Português Brasileiro. Porto Alegre: EDIPURS.

Coseriu, Eugenio. 1976[1968]. Perspectivas Gerais. In: Anthony Naro (org.). Tendências Atuais da Lingüística e da Filologia no Brasil. Rio de Janeiro: Francisco Alves.

1980[1952]. Lições de Lingü̈́stica Geral. Rio de Janeiro: Ao Livro Técnico.

Cristófaro Silva, Taïs. 2001. Fonética e Fonologia do Português: Roteiro de Estudos e Guia de Exercícios. São Paulo: Contexto.

FrançA, Ângela. 2003. Para uma Historiografia de Resolução de Problemas: da 'Arte de Dizer' na Fala Carioca às Descrições da Variante Oral do Português 
Brasileiro (1937-1960). Tese de Doutorado. Faculdade de Filosofia, Letras e Ciências Humanas, USP.

Franco de SÁ, Felipe. 1915. A Língua Portuguesa: Dificuldades e dívidas. Maranhão: [s.n.].

Grammont, Maurice. 1930. Traité de Phonétique. Paris: Delagrave.

Laudan, Larry. 1977. Progress and its Problems: Towards a Theory of Scientific Growth. London: Routledge \& Kegan Paul.

Leite, Yonne. 1986. O Pensamento Fonológico de J. Mattoso Câmara Jr. ABRALIN, 7: 17-24.

Marroquim, Mario. 1934. A Lingua do Nordeste. São Paulo: Nacional.

Mattoso CÂmara Jr., Joaquim. 1953a. Contribuição à Estilística Portuguesa. Rio de Janeiro: Ao Livro Técnico.

1953b. Para o Estudo da Fonêmica Portuguesa. Rio de Janeiro: Organização Simões. (2a. ed., preparada por Raimundo Barbadinho Neto de acordo com instruções deixadas pelo autor. Rio de Janeiro: Padrão, 1977).

1954a. Princípios de Lingüística Geral como Introdução aos Estudos Superiores da Lingua Portuguesa. 2a. ed. rev. e ampl. Rio de Janeiro: Acadêmica. (3a. ed. 1958, 4a ed. 1967.)

1954b. "Carta a Nascentes". 6 de dezembro de 1954. Ms 2pp. Universidade Católica de Petrópolis: Acervo Mattoso Câmara.

1956. Dicionário de Fatos Gramaticais. Rio de Janeiro: Casa de Rui Barbosa (2a. ed. 1964).

1960. O Problema Fonético. Súmula de aula, ministrada a convite da (C)omissão de (A)perfeiçoamento do (E)nsino (C)omercial para professores de português, em 27 de julho de 1960, 4 pp. Universidade Católica de Petrópolis: Acervo Mattoso Câmara.

1964. Dicionário de Filologia e Gramática: Referente à Língua Portuguesa. 2a. ed. Rio de Janeiro: J. Ozon. (3a. ed. 1968, 4a. ed. 1970).

1972. The Portuguese Language: History and Structure. Chicago: University of Chicago Press.

1976[1970]. Estrutura da Língua Portuguesa. Petrópolis: Vozes. 1981[1969]. Problemas de Lingüística Descritiva. Petrópolis: Vozes. (artigos publicados anteriormente na Revista Vozes entre 1968 e 1969.) Mendonça, Renato. 1936. O Português do Brasil. Rio de Janeiro: Civilização Brasileira.

Naro, Anthony Julius. 1972. Translator's Preface. In: Mattoso Câmara Jr., The Portuguese Language: History and structure. Chicago: University Press. 
Nascentes, Antenor. 1924. A Questão do Tritongo. Revista de Filologia Portuguesa, 1. 1: 13-16.

1933. O Idioma Nacional. Gramática Histórica. Rio de Janeiro: Livraria Machado/ Alves.

1937/1938. O Idioma Nacional. Rio de Janeiro/São Paulo/Recife: Nacional.

1939[1938]. Questões de Fonética. In: Estudos Filológicos. Rio de Janeiro: Civilização Brasileira.

1949. "Carta crítica a Mattoso Câmara". 4 de setembro de 1949. Universidade Católica de Petrópolis: Acervo Mattoso Câmara.

1953 [1922]. O Linguajar Carioca. 2a. ed. Rio de Janeiro: S. de Mendonça.

1954. J. Mattoso Câmara, Jr. Para o estudo da fonêmica portuguesa

- Rio, 1953. Jornal de Filologia, 2. 2-4: 300-302.

Normas Para Boa Pronúncia da Língua Nacional no Canto Erudito 1938. In: Anais do Primeiro Congresso da Lingua Nacional Cantada. São Paulo: Departamento de Cultura.

Orticica, José. 1924. Ditongos e Tritongos. Revista de Filologia Portuguesa, 1. 8-9: 149-158.

1955 [1916]. Estudos de Phonologia. In: Roteiros em Fonética Fisiológica: Técnica do Verso e Diç̧ão. Rio de Janeiro: Organização Simões. (Inclui “Teoria dos encontros vocálicos").

1955 [1938]. Carta Aberta a Nascentes ("Sistema Fonético Brasileiro"). In: Roteiros em Fonética Fisiológica: Técnica do Verso e Dicção. Rio de Janeiro: Organizações Simões.

Trubetzkoy, Nikolay 1946[1939]. Principes de Phonologie. Trad. J. Cantineau. Paris: Klincksieck.

1978[1933]. A Fonologia Atual. In: Marcelo Dascal (org.). Concepções Gerais da Teoria Lingüística, Vol. 2. São Paulo: Global.

UchôA, Carlos Eduardo Falcão 1971. O Valor dos Estudos Descritivos de Mattoso Câmara Jr. para o Ensino do Português. Littera, 2.1: 30-37. 